\title{
Draft measurement of five tyne duck foot plough in clay soil
}

\section{G. Manikandan*}

Central Institute of Agricultural Engineering - Regional Centre, Coimbatore - 641007 (Tamil Nadu), India

\section{B. Shridar}

Department of Farm Machinery and Power Engineering, Agricultural Engineering College \& Research Institute, Tamil Nadu Agricultural University, Coimbatore - 641003 (Tamil Nadu) India

\section{Manohar Jesudas}

Department of Farm Machinery and Power Engineering, Agricultural Engineering College \& Research Institute, Tamil Nadu Agricultural University, Coimbatore - 641003 (Tamil Nadu) India

*Corresponding author. Email: kandan.mani15@gmail.com

\section{Article Info}

https://doi.org/10.31018/

jans.v13iSI.2780

Received: March 22, 2021

Revised: April 17, 2021

Accepted: May 8, 2021

\section{How to Cite}

Manikandan, G. et al. (2021). Draft measurement of five tyne duck foot plough in clay soil. Journal of Applied and Natural Science, 13 (SI), 73 - 79. https://doi.org/10.31018/jans.v13iSI.2780

\begin{abstract}
In the present study, the draft requirement of five tyne duck foot plough was studied on clay soil for different soil moisture content, depth of operation and forward speed of tractor using a specially designed three-point hitch dynamometer. The designed dynamometer was matched with the tractors having category II or III hitch systems. The data acquisition system adopted for the dynamometer had NI WSN-3214 Strain Nodes, NI 9792 WSN real-time Gateway and NI LAB View 2013 software. A data logger program was developed for the three-point hitch dynamometer. The investigation was carried out at that three levels soil moisture content $(10-13 \%, 14-16 \%$ and $17-20 \%)$, at three different depth of operation $(15,20$ and $25 \mathrm{~cm})$ and three levels of the forward speed of tractor $\left(3,5\right.$ and $\left.7 \mathrm{~km} \mathrm{~h}^{-1}\right)$. The designed dynamometer performed well in all the levels of the experiment. The results showed that draft force required for five tyne duck foot plough was increased $(408 \mathrm{~kg})$ with an increase in soil moisture content $(17-20 \%)$, whereas it was increased $(408 \mathrm{~kg})$ with an increase in depth of operation $(25 \mathrm{~cm})$ and forward speed of tractor $\left(7 \mathrm{~km} \mathrm{~h}^{-1}\right)$. The suitable sweep, the forward speed of operation, depth of operation and soil moisture content that influenced the draft force and energy consumption for tillage operation of duck foot type plough were identified and developed duck foot plough was better coverage with better soil operation.
\end{abstract}

Keywords: Clay soil, Data acquisition, Draft, Five tyne duck foot plough, Three-point hitch dynamometer

\section{INTRODUCTION}

In India, several farm implements are commercially available for different field operations, such as ploughing, sowing, weeding and harvesting. Measurement of draft for particular implement in the particular soil condition is necessary for the selection of implements and power source. Tillage is a very important practice in agriculture and one of the major energy consumers in agricultural production; Estimating the amount of fuel consumption of an agricultural tractor during various tillage operations will help the selection of the best conservation practices for farm equipment (Mankagh, 2019). Draft and energy requirements, various soil conditions are important parameters for measuring and evaluating performance of tillage implements (Safari and Gazor, 2014).

Several researchers have developed different models of three point hitch dynamometers for draft of tillage implements. Designed the dynamometer, which measured resultant forces by load cells mounted in two subframes. It was designed with a quick attaching coupler for inter changeability of category III implement (Barker et al., 1981). Developed a dynamometer with most using mounted strain gauge load cells for measuring draft on tractors. It was concluded that load cell dynamometers of two types are available. The sub frame assembly between tractor and mounted implement are most commonly used. Later were integral systems of load sensing elements between tractor and mounted imple- 
ment (Bandy et al.,1986). A load cell was designed for measuring the forces of each arms. Considering the point that the lower arms of John Deere 3140 tractor are two-pieces, the load cells were designed in such a way that just the final small part of tractor had to be changed for locating the load cell. The designed load cell is located in the sliding part of the lower arm, instead of being located in the final part. This method was simple in construction and accurate. It did not make any problem in the geometry of tractor implements (. The designed, constructed and tested new triaxial dynamometer was used to measure and locate the position of all forces and moments on tillage implements, up to a maximum force of $10 \mathrm{kN}$ and a maximum moment of $9 \mathrm{~m}$. The design concept of the facility was based on four frames attached to each other by load cells and tillage tool were attached on the inner frame. Additionally, the designed setup operated desirably under field conditions. Draft measurement was compared to those predicted by ASABE Standard D497.7 and was found to be in the standard range Nobakht et al. (2017).

The dynamometer for measuring draft of mounted implements attached to three-point linkage consists of extension arms (Left and Right), load sensor, inverted T frame and head bar. To measure bending forces on the lower links, three load cells attached in sensing bodies. Prior to field tests, the three-point linkage dynamometer was calibrated. Sufficient numbers of field tests conducted to measure pull force of an implement. The developed dynamometer degree of accuracy was compared to dynamometer readings that had strain gauges in three links. A variation of $\pm 8 \mathrm{~kg}$ was observed during field trials between developed dynamometer and strain gauge dynamometer (Tewari et al. 2012).

Tractor operated five tyne duck foot plough is one of recently popularized implement being used by the farmers for primary tillage operation to plough the field. There is a lack of detailed study on the draft requirement of the tractor operated five tyne duck foot plough, which may results in low efficiency with more energy requirement.

The objective of this study was to develop an instrumentation system for measurement of draft energy requirement of various primary tillage implements and measure the draft energy requirement of five tyne duck foot plough in Tamil Nadu with the developed instrumentation system.

\section{MATERIALS AND METHODS}

A commercially available five tyne duck foot plough was taken for the draft measurement study (Fig. 1). The duck foot plough consists of a channel steel rectangular frame, rigid tines and sweeps. Leaf spring steel sweeps in the shape of duck foot are used. The sweeps are fitted fashionably to replace, when worn out. Forged mild steel was used in tynes. This plough is mostly used in hard soils for primary tillage operation. The specifications of the five tyne duck foot plough are given in Table 1.

\section{Draft measurement system}

A designed three-point hitch dynamometer was used for this present work (Fig. 2). The developed threepoint hitch dynamometer is a universal system in the manner of it can be used for various categories of implements. The three-point hitch dynamometer consisted of tractor side frame, implement side frame, load cells and telemetry data acquisition system.

The dynamometer was a double frame unit. The front side of the tractor side frame was attached to tractor hitch and rear side of implement side frame was attached to the implement. The hitch points of the implement side frame were movable for hitching with implement. The three-point hitch dynamometer can be easily connected or disconnected with the tractor and implement. Six load cells were used to measure the draft forces of implement. The three-point hitch dynamometer attached with all accessories weighed of $130 \mathrm{~kg}$. The developed three-point hitch dynamometer was attached to category II or III tractors. The design of three-point hitch dynamometer hexagonal pattern allowed mounting of Power Take-Off (PTO) driven implements without torque sensing.

The two lower links and one top link assembly was provided in the rear side of the implement end frame and the tractor side of the implement frame provided with the load cell mounted unit. The weight of the implement side frame was $60 \mathrm{~kg}$.

The designed three-point hitch dynamometer required six cylindrical load cells on three orientations. The six load cells were equally arranged in every direction, i.e., three load cells for longitudinal direction, two load cells for the vertical direction, and a single load cell for lateral direction. The load cells had maximum and minimum capacity of $2000 \mathrm{~kg}$ and $500 \mathrm{~kg}$. These load cells were connected between tractor end frame and implement end frame with eye rod end bearing.

The six load cells were connected to the Wireless Sensor Network 4-Ch Full Bridge Strain Node, each for connected three load cell. The NI WSN-3214 Strain

Table 1. Specification five tyne duck foot plough.

\begin{tabular}{lll}
\hline S. No. & Description & Dimension \\
\hline 1 & Number of tynes & 5 \\
2 & Main frame, mm & $2290 \times 550$ \\
3 & Working width, mm & 300 \\
4 & Weight, kg & 280 \\
5 & Power requirement, hp & $35-55$ \\
\hline
\end{tabular}




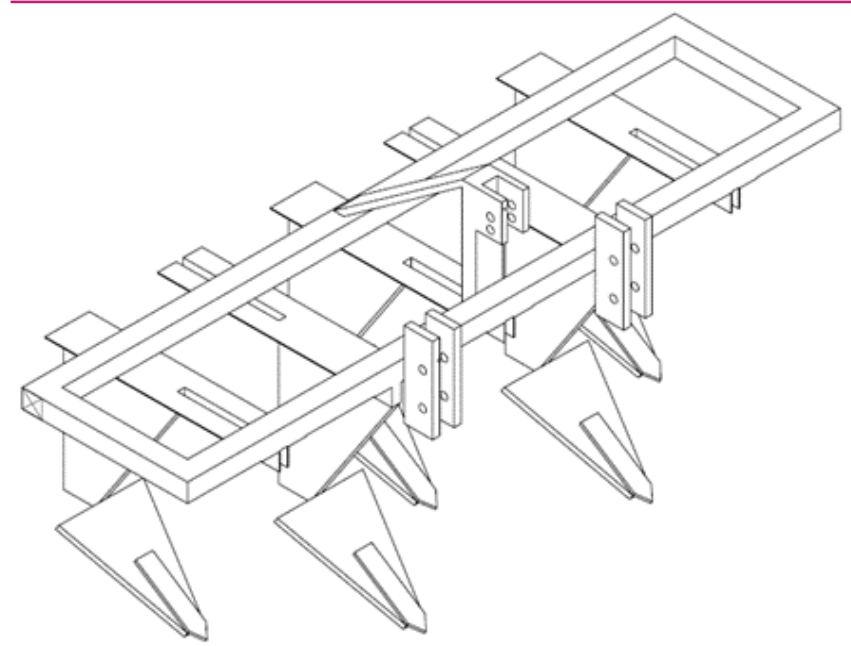

Fig. 1. Five tyne duck foot plough used for draft measurement.

Node mounted on top of the three-point hitch dynamometer in implement side frame. The data acquisition system consisted of NI WSN-3214 Strain Nodes, NI 9792 WSN real-time Gateway, computer running NI LAB View 2013 software with developed data logger program. This data acquisition system powered with $12 \mathrm{~V}, 7$ Ah DC battery in remote side of the field. The computer was utilised for running the developed data logger LAB View program.

The flow diagram for three-point hitch dynamometer data acquisition system on draft measurement of the mounted implement is shown in Fig. 3.

\section{Calibration of load cell}

The calibration of load cells was done with developed Lab VIEW program in order to determine the output quantity on input quantity characteristic. This load cell characteristic with strain gauges represented the dependence of the load cell's output voltage on the load itself. A virtual instrument was created in Lab VIEW software for measuring the output voltage of load cell. To calibrate the load cell, it is attached with an electronic balance and whole unit mounted in chain jack. The known load was applied in chain jack, as increasing manner. The mounted unit loads are verified with electronic weighing balance $(\mathrm{kg})$ and readings from Lab VIEW were noted ( $\mathrm{mV}$ ) down. After the procedure finished, the calibration curves were plotted.

\section{Force and moment components of dynamometer and Five tyne duck foot plough}

The force and moment components in the Cartesian coordinate system, as shown in Fig. 4 were computed from the following equations.

Due to small range of lateral force produced by asymmetrical implements on three-point linkage, it was neglected. Hence, the resultant (RE) derived in a two dimensional system instead of three dimensional system.
Resultant force (RE) as below,

$\mathrm{L}=\mathrm{L} 1+\mathrm{L} 2+\mathrm{L} 3$

Eq.1

$\mathrm{V}=\mathrm{V} 1+\mathrm{V} 2-\mathrm{W} \quad$ Eq.2

$\mathrm{W} \times \mathrm{XW}+\mathrm{L} 3 \times \mathrm{M}-\mathrm{L} \times \mathrm{Y}_{1}+(\mathrm{V} 1+\mathrm{V} 2) \times \mathrm{Xv}=0 \quad \mathrm{Eq} .3$

$\mathrm{RE}=\sqrt{\left[\left(L^{2}\right)+\left(V^{2}\right)\right.} \quad$ Eq.4

$\mathrm{W} \times \mathrm{Xw}+\mathrm{L} 3 \times \mathrm{M}-\mathrm{R} \times \mathrm{rr}+(\mathrm{V} 1+\mathrm{V} 2) \times \mathrm{Xv}=0 \quad$ Eq.5

Angle of resultant $(\theta)$ in $X Y$ plane,

$\theta=\arctan \left(\frac{V}{L}\right)$

$\Sigma F x, \Sigma F y$ and $\Sigma F z$ were the force components along the $x, y$ and $z$ axes. L1, L2, L3, V1, V2 and S were the forces on load cells. $a, b$ and $h$ were the position parameters of the load cells, and $\mathrm{W}$ was the weight of the sub frame and implement. The Resultant force represented in equation was the single force, resolution of horizontal and vertical components on three-point linkage, acted at a distance of (a), oriented at an angle of $(\theta)$ from the rear axle.

\section{Field test}

The factors affecting draft force and energy for tillage were soil moisture content, soil structure and cone index (Upadhyaya et al., 1984).

The field test of the three-point hitch dynamometer on the tractor and implement performance was conducted Eastern black farm Tamil Nadu Agricultural University, Coimbatore which had clay soil (Fig. 5). Soil samples were collected at 10 points to measure the soil moisture content,. The soil moisture content was measured on dry basis, for which the soil samples were weighed, oven dried at $105^{\circ} \mathrm{C}$ for $24 \mathrm{~h}$ and weighed again.

The tractor was equipped with data acquisition system and duck foot plough. The field tests were conducted to analyse the draft requirement of five tyne duck foot plough at variable soil moisture content i.e, $10-13 \%$, $14-16 \%$ and $17-20 \%$, different depth of operation i.e, 15,20 and $25 \mathrm{~cm}$ and forward speed of operation of the implement viz.,3, 5 and $7 \mathrm{~km} \mathrm{~h}^{-1}$ (Jebur and Alsayyah, 2017).

The data was stored in Lab view programme for analysis on the duck foot plough draft requirement by using the associated data acquisition system. The dynamometer was horizontally adjusted parallel to ground surface, before the conduct of the experiment. The data acquisi-tion system signal was covering up to a distance range of $30 \mathrm{~m}$.

\section{RESULTS AND DISCUSSION}

Prior to measuring the draft of mounted implements by developed three-point hitch dynamometer, the load cells mounted in dynamometer were calibrated and constants derived from calibration procedures were used to obtain forces in metric units. The horizontal 

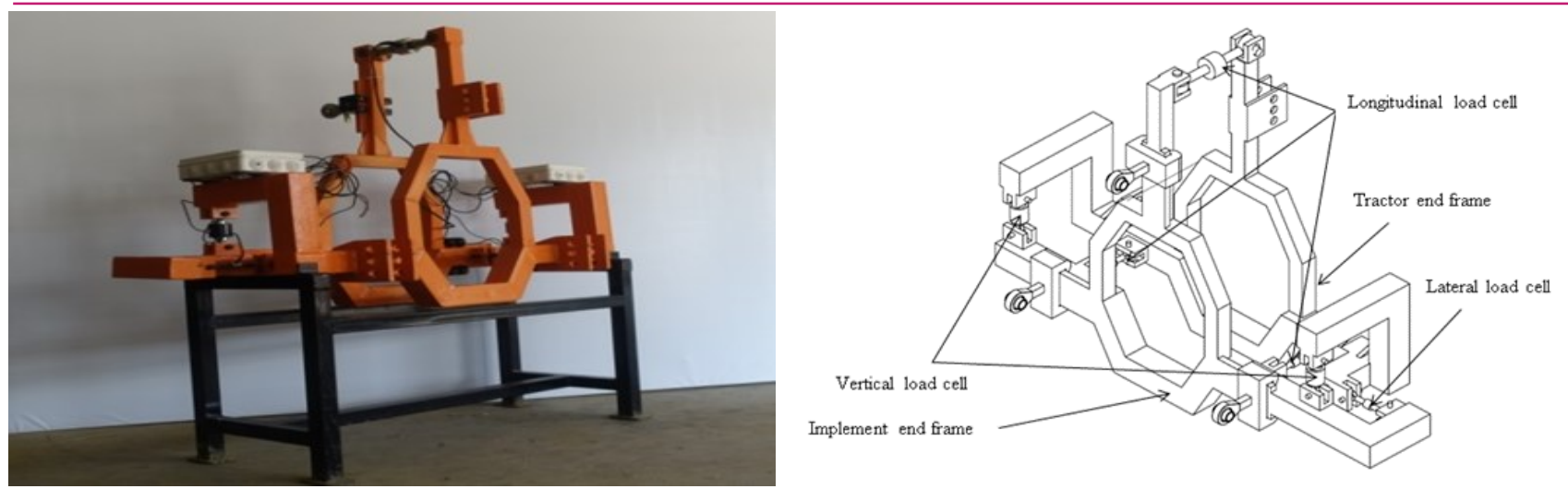

Fig. 2. Developed three point hitch dynamometer.

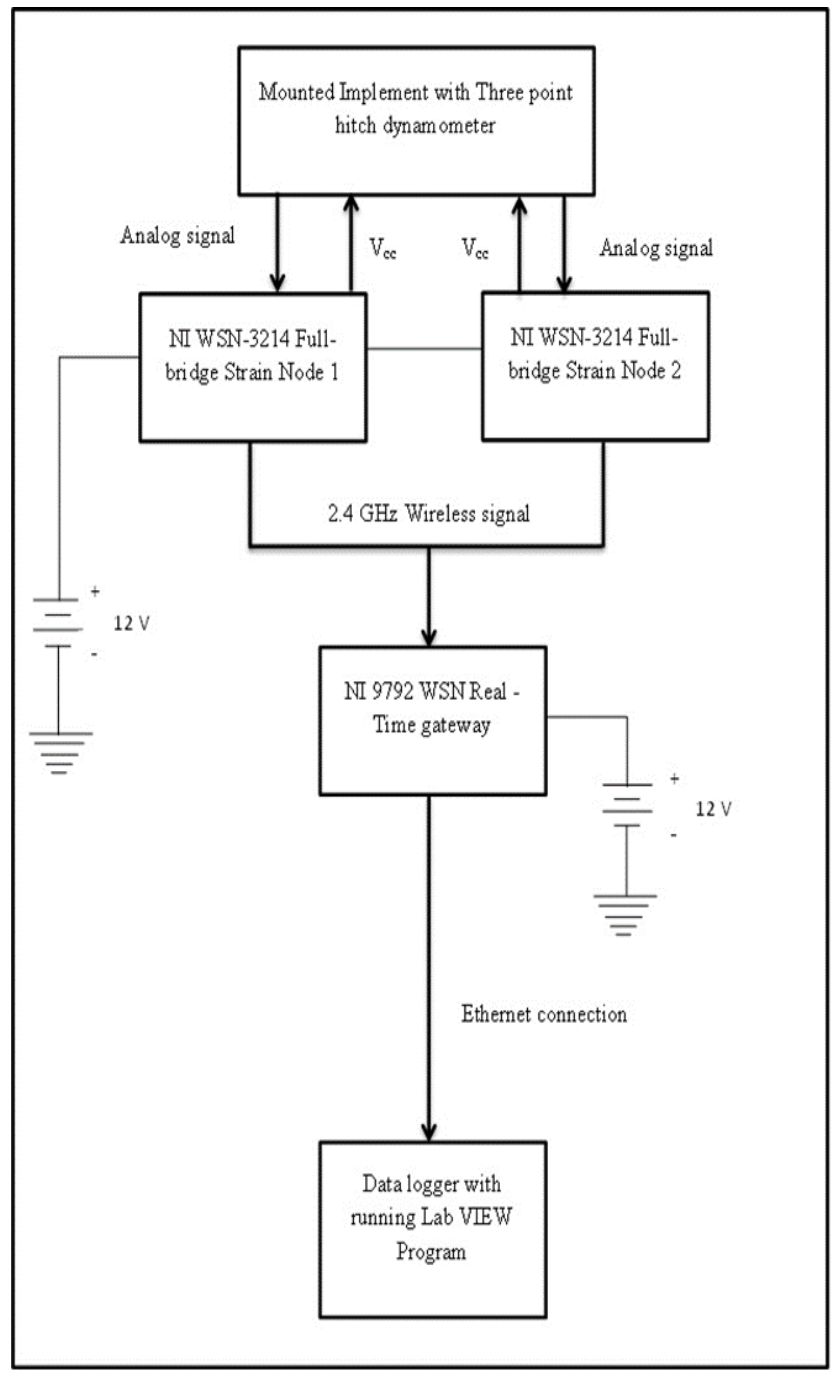

Fig. 3. Flow diagram for three-point hitch dynamometer data acquisition system on draft measurement of mounted implement.

and vertical forces of the duck foot plough were measured in the field at different soil moisture content, depth of operation and speed of travel of the implement. The average horizontal force and average vertical force measured were $405 \mathrm{~kg}$ and $68 \mathrm{~kg}$ (Fig. 6 and 7), whereas the calculated resultant force was $408 \mathrm{~kg}$ (Fig. 8).

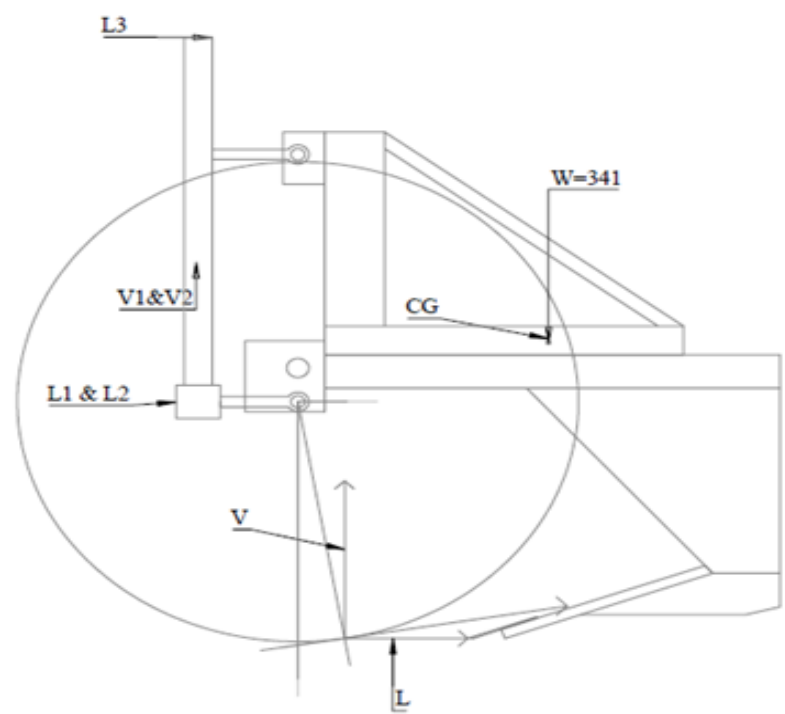

Fig. 4. Force and moment components of three-point hitch dynamometer.

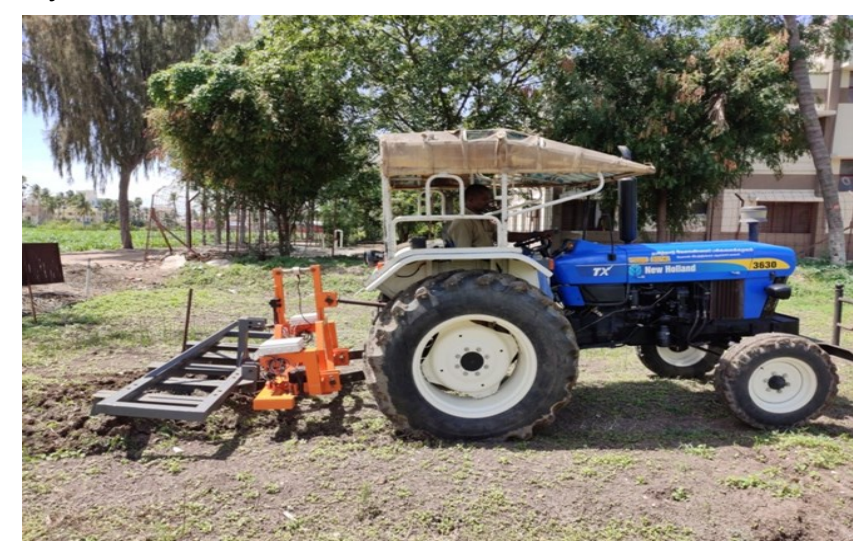

Fig. 5. Draft measurement of duck foot plough in field condition.

\section{Interactive effect of selected levels of variables on draft in clay soil}

It is observed from the Fig. 9 and Fig. 10 that the increase in forward speeds from $3 \mathrm{~km} \mathrm{~h}^{-1}$ to $7 \mathrm{~km} \mathrm{~h}^{-1}$ showed linear increase in draft for all selected levels of depth of operation with varies moisture content. Draft 


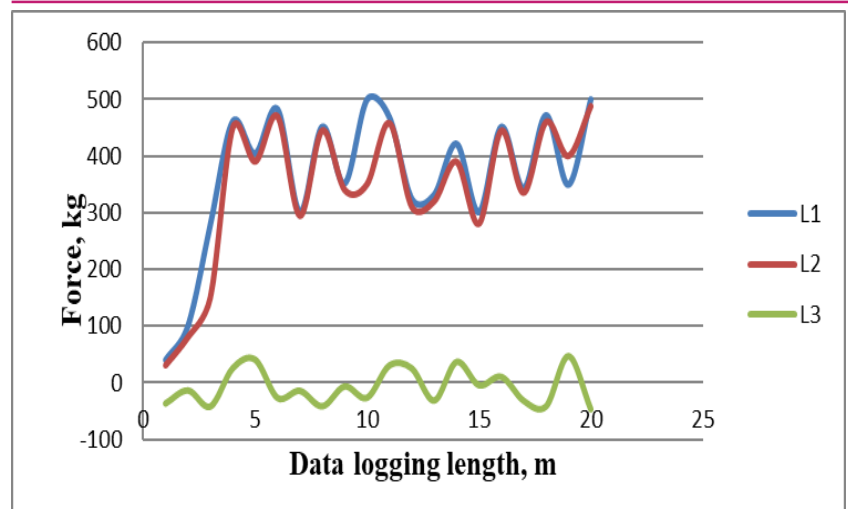

Fig. 6. Horizontal force of duck foot plough.

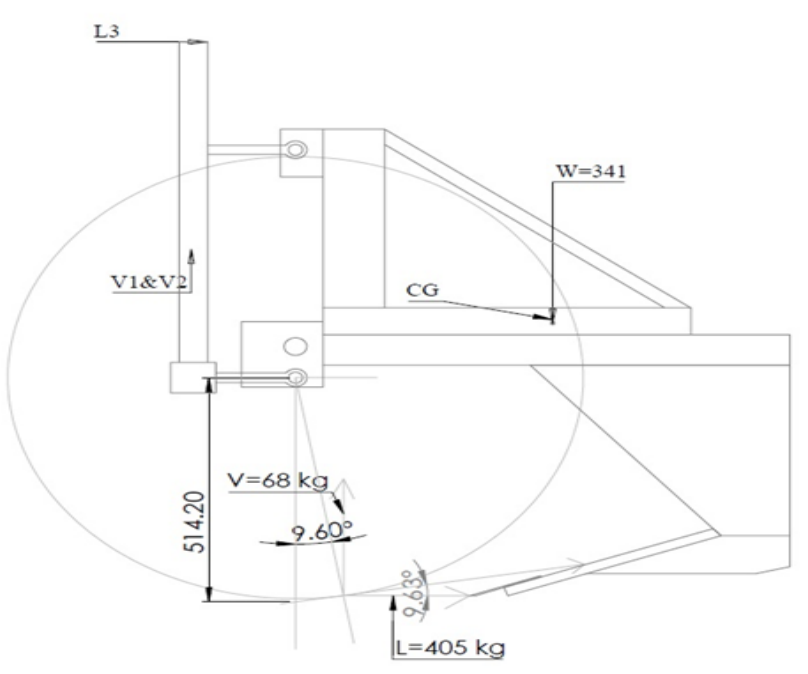

Fig. 8. Calculated resultant force of five tyne duck foot plough.

has gradual increase of 30.73 per cent in clay soil at $150 \mathrm{~mm}$ depth of operation with various moisture content. The minimum value of draft in clay soil of 378.2 $\mathrm{kg}$ was registered at $3 \mathrm{~km} \mathrm{~h}^{-1}$ (Moeinfar et al., 2014) for the treatment combination respectively. It is observed from the Fig. 9 and Fig. 10 the performance of dependent variable draft exhibited the same trend as observed with $150 \mathrm{~mm}$ depth of operation. In $200 \mathrm{~mm}$ depth of operation, it is observed that the draft values in clay

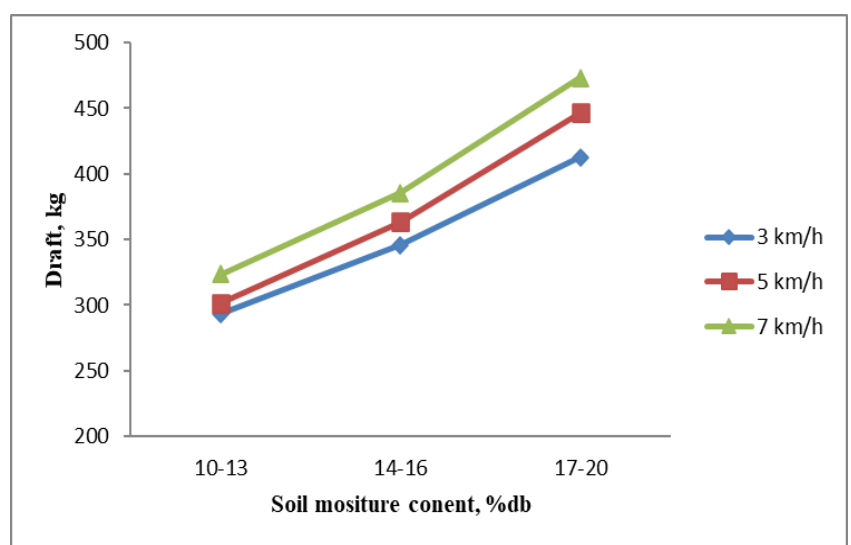

Fig. 9. Soil moisture content vs draft.

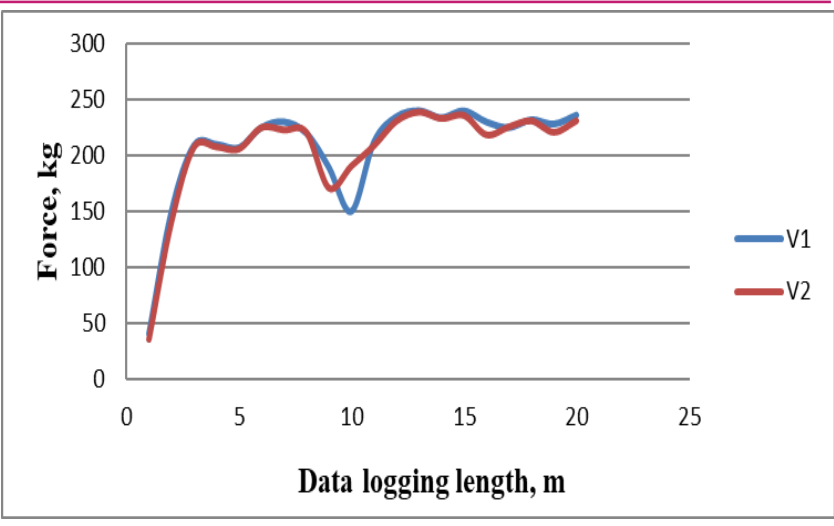

Fig. 7. Vertical force of duck foot plough.

soil was increased 30.12 per cent for all selected levels of forward speed and moisture content of soil. The minimum value of draft in clay soil of $446.93 \mathrm{~kg}$ was registered at $3 \mathrm{~km} \mathrm{~h}^{-1}$ (Jebur and Alsayyah, 2017) for the treatment combination respectively.

It is noticed that clay soil registered higher values than red soil for all the evaluation parameters that were taken for investigation. Presence of higher percentage of clay may be one of the prime reasons attributed for the increased values on the dependent variables for clay soil compared to red soil. In addition factors affecting the soil adhesion, soil-metal friction angle, draft and specific draft include the soil texture, moisture content and porosity, organic matter content (M. Manoharan 2017 ).

\section{Statistical analysis of variables}

The statistical analysis of the data was performed to assess the significance of the variables viz., forward speed of operation (S), depth of operation (D), moisture contents (M) and soil type $(C)$ on the dependent variables such as, draft.

\section{Experimental statistical design}

To statistically verify the influence of different independent variable on draft all the data were recorded and analyzed using statistical package AGRESS. The results obtained from clay soil for the analysis of variance for draft is given in Table 2 .

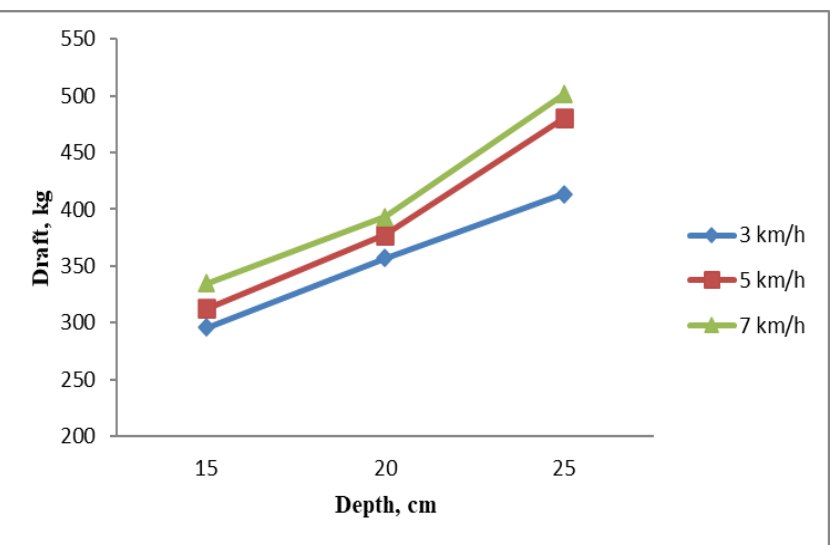

Fig. 10. Depth of operation vs draft. 
Table 2. ANOVA on draft of duck foot type plough for clay soil.

\begin{tabular}{llllll}
\hline SI. No. & SV & DF & SS & MSS & F \\
\hline 1 & Depth (D) & 2 & 290031.86 & 145015.93 & $496.22^{* *}$ \\
2 & Error (a) & 4 & 1168.95 & 292.23 & $729.38^{* *}$ \\
3 & Moisture Content (M) & 2 & 186659.58 & 93329.79 & $11.46^{* *}$ \\
4 & D x M & 4 & 5869.20 & 1467.30 & 127.95 \\
5 & Error (b) & 12 & 1535.47 & 83815.93 & $601.60^{* *}$ \\
6 & Speed (S) & 2 & 167631.87 & 7594.34 & $7.56^{* *}$ \\
7 & D x S & 4 & 4216.14 & 813.77 & $5.84^{* *}$ \\
8 & M x S & 4 & 3255.09 & 306.87 & $2.20^{*}$ \\
9 & D x M x S & 8 & 2454.96 & 139.31 & \\
10 & Error (c) & 36 & 5015.50 & & \\
11 & Total & 80 & 668215.99 & & \\
\hline
\end{tabular}

C.V. (Treatment): $1.82 \%$; ${ }^{* *}=$ significant at $1 \%$ level $\quad{ }^{*}=$ significant at $5 \%$ level $\quad n s=$ not significant

The Fig. 9 and 10 showed the draft measured in $\mathrm{kg}$ at different soil moisture content and at different depth, respectively. From the graph, it was observed that the draft was increased with increase in moisture content for all forward speed of operation of the implement. The maximum draft was observed with $17-20 \%$ moisture content at $7 \mathrm{~km} \mathrm{~h}^{-1}$ speed.

It was revealed that the draft was increased with increase in depth of operation of the implement for all forward speed of the tractor, whereas the maximum was observed with $25 \mathrm{~cm}$ depth at $7 \mathrm{~km} \mathrm{~h}^{-1}$ speed.

\section{Conclusion}

The present study concluded that the developed dynamometer performed well in all the levels of the draft force measurement experiments. The horizontal and vertical forces measured were $405 \mathrm{~kg}$ and $68 \mathrm{~kg}$ and the calculated resultant force was $408 \mathrm{~kg}$. The draft was increased with an increase in moisture content for all forward speed of operation of the implement. The maximum draft was observed with 17-20 \% moisture content at $7 \mathrm{~km} \mathrm{~h}^{-1}$ speed. The draft was having direct relationship with depth of operation; while the increasing depth of operation, the draft of the implement was also increased and attained the maximum value at 25 $\mathrm{cm}$ depth of $7 \mathrm{~km} \mathrm{~h}^{-1}$ forward speed. Hence, reduced draft techniques have now been identified and recognized as an alternate to bridge the need and better working quality of tillage operations apart from reducing energy consumption, minimizing tractive effort and increased area of coverage with better soil operation.

\section{Conflict of interest}

The authors declare that they have no conflict of interest.

\section{REFERENCES}

1. Bandy, S. M., Babacz, W. A., Searcy, S. W., \& Stout, B. A. (1986). Measurement of three-point hitch forces on agricultural tractors (No. 861255). SAE Technical Paper.

2. Barker, G. L., L. A. Smith, L. A. \& R. F. Colwick, R. F. (1981). Three-point hitch dynamometer for directional force measurement. ASAE Paper No. 81-1044, St. Joseph, MI: ASAE.

3. Beigi, M., Ghazavi, M.A. \& Ahmadi, I. (2014). Design and construction of load cell of a three point hitch dynamometer for tractor john deere 3140. Journal of Modern Processes in Manufacturing and Production, 3 (2), 47-58.

4. Jebur, H.A., \& Alsayyah, Y.A.A. (2017). Study of the soil moisture content and the tractor speed on the performance efficiency of the machinery unit. OSR Journal of Agriculture and Veterinary Science, 10, 65-70.

5. Mankagh Amer M. (2019). Review of fuel consumption, draft force and ground speed measurements of the agricultural tractor during tillage operations. Asian Journal of Advanced Research and Reports, 3(4), 1-9.

6. Manoharan, M. (2017). Effect of soil adhesion on mould board plough as influenced by surface configuration and coating material. Unpublished Ph.D. Thesis. Department of Farm Machinery, Tamil Nadu Agricultural University, Coimbatore, India.

7. Moeinfar, A., Mousavi-Seyedi, S. \& Kalantari, D. (2014). Influence of tillage depth, penetration angle and forward speed on the soil/thin-blade interaction force. Agricultural Engineering International: CIGR Journal, 16 (1), 69-74.

8. Nobakht, N., Askari, M., Nikbakht, A.M. \& Ghorbani, Z. (2017). "Development of a dynamometer to measure all forces and moments applied on tillage tools." MAPAN 32 (4),311-319.

9. Safari, M., \& Gazor, H. R. (2014). Comparison of conventional tractors performance during primary tillage in Iran. Agric Eng Int: CIGR Journal, 16(1), 61-68. 
10. Tewari, V., N. Ravi, K. Jha, \& A. Ashok. (2012). Design and development of a three-Point-linkage dynamometer for tillage research. Agricultural Engineering Today 36 (3),33-38.
11. Upadhyaya, S. K., Williams, T. H., Kemble, L. J., \& Collins, N. E. (1984). Energy requirements for chiseling in coastal plain soils. Transactions of the ASAE, 27(6), 16431649. 